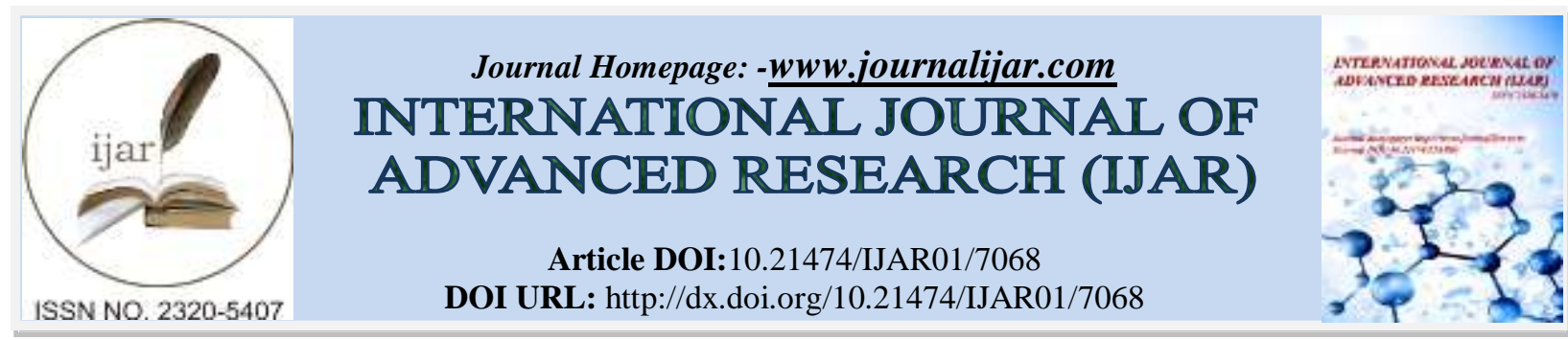

RESEARCH ARTICLE

\title{
STUDIES ON OXIDATIVE STRESS MARKERS OF ALLOXAN -INDUCED DIABETIC WISTAR RATS TREATED WITH TETRACARPIDIUM CONOPHORUM AND PIPER GUINEENSE (1:1 MIXTURE).
}

\author{
Obomanu. F. $\mathrm{G}^{\mathbf{1}}$ and Dokubo. $\mathrm{A}^{2}$. \\ 1. Dept. of Chemistry, Rivers State University, P.M.B. 5080, Port Harcourt, Nigeria. \\ 2. Dept. of Biochemistry, Rivers State University, P.M.B. 5080, Port Harcourt, Nigeria.
}

\section{Manuscript Info}

Manuscript History

Received: 10 March 2018

Final Accepted: 12 April 2018

Published: May 2018

Keywords

Glucose, Tetracarpidium Conophorum,

Piper Guineense, Oxidative Stress, Alloxan.

\begin{abstract}
This study was designed to investigate the glucose levels and markers of oxidative stress on alloxan- induced diabetic wistar rats treated with ethanolic leaf extracts of 1:1 mixture of Piper guineense (PG) and Tetracarpidium conophorum (TC). A total of thirty rats weighing between 100-150g were used for this study. They were divided into six (6) groups comprising Normal control (received distilled water), Negative control (received $100 \mathrm{mg} / \mathrm{kg}$ body weight of alloxan), Positive control $(2.5 \mathrm{mg} / \mathrm{kg}$ body weight $)$ and test groups which received $300 \mathrm{mg} / \mathrm{kg}$ body weight of Ethanol Extract of $P$. guineense (EAPG2), Ethanol Extract of $T$. conophorum (EATC3), Ethanol Extract of $P$. guineense $+T$. conophorum in ratio1:1 (EAPGTC4). Diabetes was induced by intraperitoneal administration of $100 \mathrm{mg} / \mathrm{kg}$ body weight of alloxan (A) for seven days. After treatment, the result showed that fasting blood glucose level in the test groups had significant $(\mathrm{p}<0.05)$ decrease when compared to the alloxan treated group only. Also, the oxidative stress markers indicated significant $(p<0.05)$ decrease in malondialdehyde (MDA) and significant $(\mathrm{p}<0.05)$ increase in antioxidant enzymes superoxide dismutase (SOD), catalase( CAT) and reduced gluthatione (GSH) comparable to test groups. Histopathological examination of the pancreas and liver tissue showed recovering and good cellularity on the pancreas and liver tissues. From the findings of this study, it can be concluded that $300 \mathrm{mg} / \mathrm{kg}$ body weight of $P$. guineense and $T$. conophorum (1:1 mixture) exhibited hypoglycemic and antioxidant potentials ameliorating damages brought about by alloxan.
\end{abstract}

Copy Right, IJAR, 2018,. All rights reserved.

\section{Introduction}

Oxidative stress refers to a state of imbalance between pro-oxidants( reactive oxygen species, ROS) or free radicals and antioxidants (AO) of a body system. When the antioxidants of the body defense system are inactivated, $\mathrm{ROS} / \mathrm{AO}$ equilibrium is altered favouring stress (Ibrahim et al., 2012). These radicals, when tightly regulated, serve as intracellular signaling molecules (Klein and Ackerman, 2003). Accumulation of these radicals can become harmful and can cause damage to tissues by reacting with biomolecules such as lipids in cellular membranes, nucleotides in DNA and essential functional groups in proteins and carbohydrate contributing to the pathogenesis of many chronic diseases such as diabetes. Diabetes is characterized by elevated levels of glucose in the blood. Glucose 
is regulated by insulin, an hypoglycemic hormone secreted by the pancreatic $\beta$ - cells. Deficiency or insensitivity to insulin receptors results to Type 1 and Type 2 diabetes respectively.

Exposure to some chemicals, viruses, environmental pollutants and drugs preferentially destroys pancreatic $\beta$ - cells by free radical generation mechanism which results to impairment in insulin secretion and action giving rise to diabetic diseases (Costa and Mordis-Ferreira, 2001). Various free radicals have been implicated in oxidative stress induced pancreatic $\beta$-cell destruction (Stumvoll et al., 2005., Ozougwu et al., 2013) that can initiate chronic immune-mediated destruction of pancreatic $\beta$-cells, partial or absolute insulin deficiency that occurs at a variable rate and becomes clinically symptomatic when approximately $90 \%$ of pancreatic $\beta$-cells are destroyed or dysfunctional (Knip, 2011).

Given the cellular nature of dysfunction of key diabetic organs, many researchers across the globe strive to evaluate the multifaceted nature of the disease in order to develop best strategies for understanding the pathophysiology and design of therapies to combat it.

Medicinal plants contain different secondary metabolites also known as phytochemicals which have been reported to exhibit antihyperglycemic effects singly or in combination (Baldi and Goyal, 2011., Petchi et al., 2014.,Obomanu et al., 2017). Piper guineense and Tetracarpidium conophorum are popular plants in Nigeria (Akomolafe et al., 2015., Ojinaka et al., 2016). Tetracarpidium conophorum (Mull. Arg.) Hutch. \& Dalziel ( Euphorbiaceae) is commonly called African walnut (Ukpa in Igbo). Its nuts are cooked and taken as snacks (Amaeze et al., 2011) while the leaves are employed in treatment of illnesses such as treat toothache, syphilis, dysentery and as antidote to snakebite (Obomanu et al., 2017). Piper guineense (Schumach) is of the Piperaceae family. It is commonly called Ashanti pepper or black pepper (Uziza in Igbo). The seeds are commonly used as spice in prepation of soups. The nutritional as well as the mineral components of the seeds have been investigated (Obomanu et al., 1991). The leaves have also been investigated for anti-microbial, antifungal and antioxidant activity (Ojinaka et al., 2016).

This study is aimed at investigating glucose levels and oxidative stress markers in alloxan -induced diabetic wistar rats treated with ethanol extracts of Tetracarpidium conophorum and Piper guineense leaves (1:1 ratio).

\section{Materials and Methods:-}

\section{Collection and Identification of Plant Materials:}

Fresh leaves of Tetracarpidium conophorum and Piper guineense were collected from Oke-oko

village in Owena L.G.A of Ondo State and Mile 1Market Port Harcourt, Rivers State respectively. The plants were authenticated at the Plant Science and Biotechnology Department, Rivers State University, Port Harcourt Nigeria. The plants were shade-dried for 5 days in the laboratory at room temperature $\left(29-30^{\circ} \mathrm{C}\right)$ and milled to a coarse powder using a grinder.

\section{Preparation of the Extracts:}

A known weight, $70 \mathrm{~g}$ of the powder was extracted by maceration with $600 \mathrm{ml}$ of $80 \%$ ethanol at room temperature for 4 days and filtered with a clean muslin cloth and the filtrate evaporated to dryness in an oven at a temperature of $40-50^{\circ} \mathrm{C}$. The extracts were re-suspended in distilled water and dose administered according to the body weight of animals (Erhirhie et al., 2014).

\section{Chemicals and Reagents:}

Alloxan monohydrate was procured from Sigma Company, St. Louis, USA and Glibenclamide (Daonil 5mg) from Safonis Aventis, India. All other reagents and chemicals used for this study were of analytical grade supplied by the Department of Biochemistry, Rivers State University, Port Harcourt, Nigeria.

\section{Experimental Animals:}

Thirty- five wistar albino rats, weighing $(100-200 \mathrm{~g})$ were used for the study. They were obtained from the animal house of University of Port Harcourt and allowed to acclimatize in the animal house of the Department of Biochemistry, Rivers State University, Port Harcourt, Nigeria for seven (7) days. Feeds and water were provided ad libitum. The experiment was conducted according to the University's ethical guidelines of the use of laboratory animals. 
Table 1:-Treatment Procedure for the Experimental Rats

\begin{tabular}{|l|l|l|}
\hline S/N & Group Identity & Treatment \\
\hline 1 & Normal Control & Received distilled water only \\
\hline 2 & Negative Control & Received $100 \mathrm{mg} / \mathrm{kg} \mathrm{B.W}$ of alloxan only \\
\hline 3 & Positive Control (AG1) & Received standard drug $(2.5 \mathrm{mg} / \mathrm{kg}$ of glibenclamide) \\
\hline 4 & EAPG2 & Ethanol Extract of $P$. guineense $(300 \mathrm{mg} / \mathrm{kg}$ body) \\
\hline 5 & EATC3 & Ethanol Extract of $T$. conophorum $(300 \mathrm{mg} / \mathrm{kg}$ body) \\
\hline 6 & EAPGTC4 & $\begin{array}{l}300 \mathrm{mg} / \mathrm{kg} \text { body weight of Ethanol Extract of } P . \text { guineense }+T . \\
\text { conophorum (ratio1:1) }\end{array}$ \\
\hline
\end{tabular}

\section{Preparation of Standard Drug:}

Glibenclamide tablets, an oral hypoglycaemic drug, were used as reference drug. This was freshly prepared in distilled water and administered at a dose of $2.5 \mathrm{mg} / \mathrm{kg}$ body weight orally.

\section{Induction of diabetes:}

The rats were kept fasting for 18 hours and injected with $100 \mathrm{mg} / \mathrm{kg}$ of alloxan monohydrate in normal saline intraperitoneally using insulin syringes. The rats were kept for 24 hour on a $10 \%$ glucose solution to prevent fatal hypoglycemia. After one hour, the animals were provided feed ad libitum. After 48hours of administration, animals were considered hyperglycemic when the blood glucose level was raised above $200 \mathrm{mg} / \mathrm{dl}$ using a gluccometer. The selected hyperglycemic rats were grouped and administered with the plants materials for seven days

\section{Collection of Organs:-}

At termination of the experiment, animals were fasted overnight. They were sacrificed by cervical dislocation. Incisions were quickly made in cervical region of the sacrificed animals using a sterile blade and the organs excised and transferred into properly labeled sample bottle for biochemical investigation.

\section{Preparation of Liver Homogenate:}

The liver of the rats was removed and washed in cooled $0.9 \% \mathrm{NaCl}$, kept on ice and subsequently blotted on filter paper, then weighed and homogenized in cold phosphate buffer $(0.05 \mathrm{M}, \mathrm{pH} 7.4)$. The homogenates were centrifuged at $10,000 \mathrm{~g}$ for 10 minutes to obtain the supernatant for determination of oxidative stress markers.

\section{Determination of Fasting Blood Glucose Concentration:}

The glucose in plasma was assayed using the (Accu check glucometer), containing a glucose strips and glucometer. The principle involves the sample glucose reacting with available glucose oxidase enzyme in strip which serves as electrode through which oxidation of glucose into gluconic acid occurs with the transfer of electrons the enzyme. At the electrode surface, re-oxidation of reduced enzyme provides amperometric signal, whose magnitude was equivalent to glucose in sample.

\section{Determination of Superoxide dismutase (SOD) Activity:}

SOD was determined by the method of auto-oxidation of pyrogallol (Marklund and Marklund, 1974). Pyrogallol autoxidizes rapidly in alkaline solution generating superoxide ions. SOD inhibits its auto-oxidation, dismutating the superoxide ions to hydrogen and molecular oxygen. The activity of 50\% inhibition by SOD was measured spectrophtometrically at $420 \mathrm{~nm}$.

\section{Determination of Catalase (CAT) Activity:}

The activity of catalase was determined by the method of Sinha (1972). Catalase in the enzyme source splits hydrogen peroxide at different times. At a specific time interval, the reaction is stopped by the addition of dichromate/ acetic acid reagent. When heated in the presence of hydrogen peroxide, dichromate in acetic acid is reduced to chromic acetate and unstable perchromic intermediate. The remaining hydrogen peroxide can be determined by reading the absorbance of chromic acetate formed at a wavelength of $610 \mathrm{~nm}$.

\section{Determination of Reduced Glutathione (GSH) Concentration:-}

GSH was estimated by the method of Ellmans reagent (ElIman, 1959). The method involves the development of a yellow color using Ellmans reagent, 5, 5-dithio-bis- 2-nitribenzoic acid (DTNB) to compounds containing sulphydryl groups. The absorbance is read at $412 \mathrm{~nm}$. 


\section{Determination of Lipid Peroxidation (LPO)}

LPO was determined by the malondialdehyde (MDA), a product of lipid peroxidation according to the method described by Devasagayam et al. (2003). In this method, the samples were heated with thiobarbituric acid (TBA) reagent for 20 minutes in a boiling water bath. MDA, a product of lipid peroxidation reacts with TBA to give a pink colored product which is read at $535 \mathrm{~nm}$.

\section{Statistical Analysis:}

Data were expressed as Mean \pm SEM. The data were subjected to one way analysis of variance (ANOVA) followed by the turkey post hoc test for comparison tests to assess difference between groups. The values of $p<0.05$ were considered statistically significant.

\section{Results:-}

\section{Effect of Treatment on Fasting Blood Glucose in the Alloxan Treated Rats:}

The result obtained for the fasting blood glucose level in Table 2, shows that glucose levels in all the rats before administration of alloxan was not significant ( $\mathrm{p}>0.05$ ) compared to the control. After induction, the groups that received alloxan had significant $(\mathrm{p}<0.05)$ increase in fasting blood glucose when compared to the control. After the treatment, the test groups (EAPG2, EATC3 and EATCPG4) and the positive control (AG1) indicated significant $(\mathrm{p}<0.05)$ decrease in glucose concentration compared to the negative control administered with alloxan only.

Table 2:-Glucose levels (mg/dl) in the Experimental Rats

\begin{tabular}{|l|l|l|l|l|}
\hline S/N & Group Identity & Before induction & After Induction & After Treatment \\
\hline 1 & Normal Control & $66.72 \pm 0.64^{\mathrm{a}}$ & $65.76 \pm 1.27^{\mathrm{a}}$ & $67.31 \pm 5.32^{\mathrm{a}}$ \\
\hline 2 & Negative Control & $67.69 \pm 5.05^{\mathrm{a}}$ & $218.12 \pm 3.57^{\mathrm{b}}$ & $220.36 \pm 3.38^{\mathrm{b}}$ \\
\hline 3 & Positive Control & $65.57 \pm 0.58^{\mathrm{a}}$ & $215.74 \pm 2.85^{\mathrm{b}}$ & $131.67 \pm 3.01^{\mathrm{e}}$ \\
\hline 4 & EAPG2 & $68.65 \pm 4.38^{\mathrm{a}}$ & $210.34 \pm 2.18^{\mathrm{b}}$ & $188.52 \pm 0.76^{\mathrm{c}}$ \\
\hline 5 & EATC3 & $61.60 \pm 3.12^{\mathrm{a}}$ & $213.33 \pm 5.41^{\mathrm{b}}$ & $179.58 \pm 0.98^{\mathrm{c}}$ \\
\hline 6 & EAPGTC4 & $62.87 \pm 5.02^{\mathrm{a}}$ & $217.45 \pm 1.03^{\mathrm{b}}$ & $153.71 \pm 7.26^{\mathrm{d}}$ \\
\hline
\end{tabular}

Values are expressed as Mean \pm S.E.M ( $n=3$ ). Means with different superscript (a-c) are significantly different (Turkey HSD, $p<0.05$ ).

\section{Effect of Treatment on Oxidative Stress Markers}

The result obtained for the level of oxidative stress markers is presented in Table 3. The result showed significant $(\mathrm{p}<0.05)$ increase in MDA and significant $(\mathrm{p}<0.05)$ decrease in antioxidant enzymes (SOD, CAT and GSH) in the alloxan treated group compared to normal control. There was significant $(\mathrm{p}<0.05)$ decrease in MDA and significant $(\mathrm{p}<0.05)$ increase in the antioxidant enzymes of the groups administered with the extracts (EAPG2, EATC3 and EAPGTC4) compared to the alloxan treated group (negative control). However significant $(\mathrm{p}<0.05)$ difference was observed for CAT when compared to the reference drug treated (positive control) group.

Table 3:- Effect of Treatment on Oxidative Stress Markers

\begin{tabular}{|l|l|l|l|l|l|}
\hline S/N & $\begin{array}{l}\text { Group } \\
\text { Identity }\end{array}$ & $\begin{array}{l}\text { MDA } \\
(\mathrm{nmol} / \mathrm{mg} \text { protein })\end{array}$ & $\begin{array}{l}\text { SOD } \\
(\mathrm{U} / \mathrm{mg} \text { protein })\end{array}$ & $\begin{array}{l}\text { CAT } \\
(\mathrm{U} / \mathrm{mg} \text { protein })\end{array}$ & $\begin{array}{l}\text { GSH } \\
(\mu \mathrm{mol} / \mathrm{mg} \text { protein })\end{array}$ \\
\hline 1 & $\begin{array}{l}\text { Normal } \\
\text { Control }\end{array}$ & $40.32 \pm 0.74^{\mathrm{a}}$ & $85.75 \pm 1.27^{\mathrm{a}}$ & $90.31 \pm 1.21^{\mathrm{a}}$ & $75.06 \pm 0.57^{\mathrm{a}}$ \\
\hline 2 & $\begin{array}{l}\text { Negative } \\
\text { Control }\end{array}$ & $89.69 \pm 1.05^{\mathrm{b}}$ & $51.12 \pm 1.03^{\mathrm{b}}$ & $53.36 \pm 0.38^{\mathrm{b}}$ & $55.78 \pm .38^{\mathrm{b}}$ \\
\hline 3 & $\begin{array}{l}\text { Positive } \\
\text { Control }\end{array}$ & $45.57 \pm 1.55^{\mathrm{c}}$ & $80.74 \pm 1.85^{\mathrm{c}}$ & $91.67 \pm 0.09^{\mathrm{a}}$ & $70.34 \pm 1.30^{\mathrm{c}}$ \\
\hline 4 & EAPG2 & $60.75 \pm 1.38^{\mathrm{d}}$ & $82.11 \pm 1.18^{\mathrm{c}}$ & $88.52 \pm 0.76^{\mathrm{c}}$ & $67.01 \pm 1.67^{\mathrm{c}}$ \\
\hline 5 & EATC3 & $67.60 \pm 1.19^{\mathrm{d}}$ & $83.33 \pm 5.41^{\mathrm{c}}$ & $79.58 \pm 0.98^{\mathrm{d}}$ & $63.46 \pm 1.48^{\mathrm{d}}$ \\
\hline 6 & EAPGTC4 & $62.87 \pm 1.11^{\mathrm{d}}$ & $80.12 \pm 1.34^{\mathrm{c}}$ & $83.71 \pm 0.27^{\mathrm{c}}$ & $69.12 \pm 0.62^{\mathrm{c}}$ \\
\hline
\end{tabular}

Values are expressed as Mean \pm S.E.M (n=3). Means with different superscript (a-c) are significantly different (Turkey HSD, p<0.05). 


\section{Histopathological Observation of Pancreas and Liver of the Experimental Rats:-}
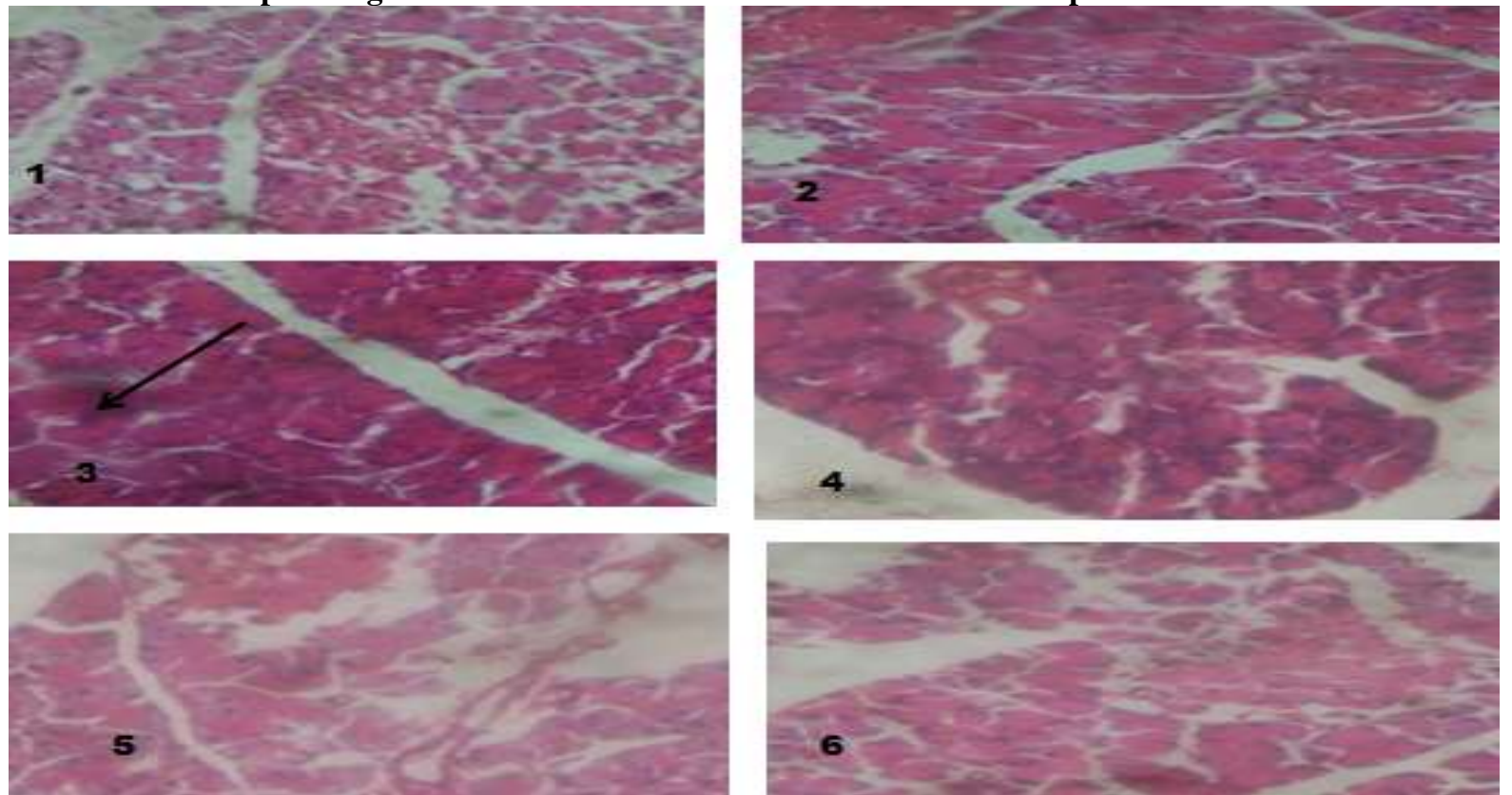

Figure 1:-The List of Plates Showing Pancreas of the Rats ( $\times 400 \mathrm{H} \& \mathrm{E})$. Plate 1: Normal control rats showing normal intact islets. Plate 2: Negative control showing swollen $\beta$ - cells. Plate 3: Positive control showing normal islets. Plate 4: EAPG2 treated group showing mild distorted $\beta$ - cells. Plate 5: EATC3 treated group showing mild distorted $\beta$-cells. Plate 6: EAPGTC4 treated group showing mild distorted $\beta$ - cells.
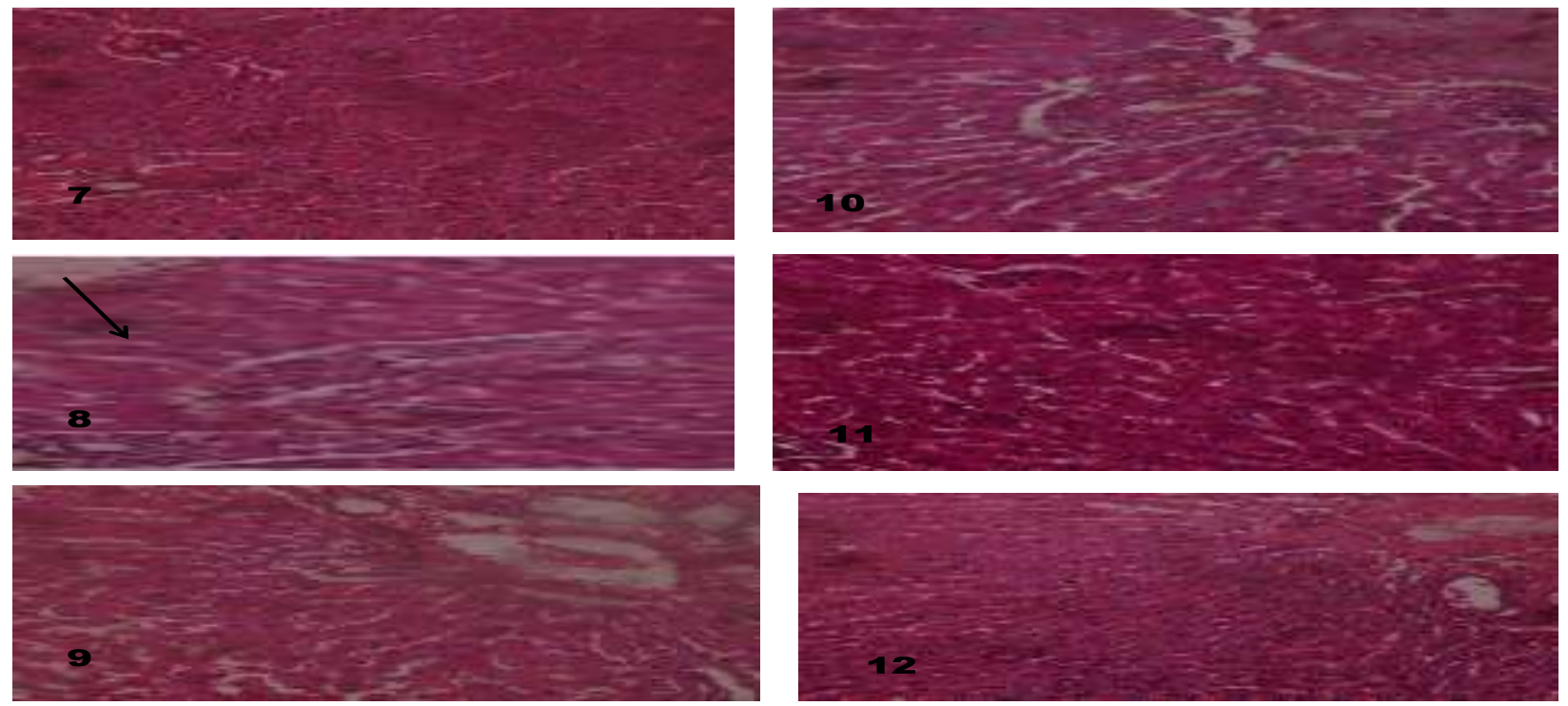

Figure 2:-The List of Plates Showing Liver Sections of the Rats ( $\times 400 \mathrm{H} \& \mathrm{E})$ Plate 7: Normal control showing normal hepatocytes and peripotal vein. Plate 8: Negative control showing periportal inflammation. Plate 9: Positive control showing normal hepatocytes. Plate 10: EAPG2 treated group showing mild inflammation. Plate 11: EATC3 treated group showing mild inflammation. Plate 12: EAPGTC4 treated group showing mild inflammation.

\section{Discussion:-}

Alloxan is an unstable and hydrophilic chemical compound that has similar structure with glucose. This structural similarity allows it to be transported into cytosol by (GLUT2) in the plasma membrane of $\beta$ - cells for selective uptake and accumulation in the pancreatic $\beta$ - cells. It is a well- known diabetogenic agent that is used to induce diabetes with characteristics similar to type1 in experimental animals (Carvalho and DaCosta, 2009). The drug has been noted to exert its diabetogenic effects when administered parenterally, i.e., intravenously, intraperitoneally or 
subcutaneously. From this study, the increase in glucose concentration observed in the groups administered with alloxan could be due to decreased secretion of insulin in response to complete destruction of pancreatic $\beta$ - cells by alloxan. Alloxan evokes a sudden rise in insulin secretion within minutes of its administration followed by complete suppression of the pancreatic $\beta$ - cells and rapid uptake establishing a redox cycle for the generation of reactive oxygen species (ROS) and superoxide radicals through the Fenton reaction in the presence of iron (II) oxide and $\mathrm{H}_{2} \mathrm{O}_{2}$. This has been proposed to be one of the most important mechanisms of alloxan diabetogenicity (Peschke $e t$ al., 2005, Ankur and Shahjad, 2012). However, administration of $300 \mathrm{mg} / \mathrm{kg}$ body weight of ethanol extracts of $P$. guineense and $T$. conophorum exhibited significant decrease in fasting glucose concentration compared to the alloxan treated group. This is an indication of the anti-hyperglycemia effects of the extracts which may be attributed to enhanced uptake of glucose for the production of ATP. Similar results were also reported by Obomanu et al. (2017). Administration of $300 \mathrm{mg} / \mathrm{kg}$ body weight of combined extracts of $P$. guineenseand T. conophorum in the ratio (1:1) caused $38.61 \%$ reduction in fasting blood glucose level over a period of 7 days comparable with the reference drug treated groups $(37.87 \%)$ which received $2.5 \mathrm{mg} / \mathrm{kg}$ body weight of glibenclamide a hypoglycemic agent. Groups treated singly with ethanol extract of $P$. guineense and $T$. conophorum had glucose reduction of 28.1 $\%$ and $25.8 \%$ respectively which was statistically similar.

Alloxan also inhibits many other cellular functions of enzymes and biochemical pathway via oxidation of thiol present in hexokinase, phosphofructokinase, calmodulin-dependent protein kinase, aconitase and other proteins resulting to influx of enzymes into blood circulation and secondary pathophysiological changes on different organs of the body (Das et al., 2012). In this study, the groups administered with alloxan had significant decrease in hepatic content of antioxidant enzymes (SOD, CAT and GSH) and increased level of malondialdehde (MDA), a product of lipid peroxidation. This is an indication of oxidative stress and excess production of ROS. MDA is a product or marker of lipid peroxidation (LPO), a well established reaction mechanism proposed for cellular damage in man and experimental animals (Li et al., 2010). Increased levels of MDA have also been reported in many chronic diseases in both man and animals (Li et al., 2010). In cells, oxidative stress can result to a shift in mitochondria redox potential favouring production of excess ROS and depletion of antioxidant enzymes (Schafer and Buethner, 2001). ROS also called free radicals which have the ability to reversibly or irreversibly damage many biomolecules, change the properties of membranes and organs and trigger the pathogenesis of diabetes (Uddin et al., 2008, Dokubo et al., 2017a).

Antioxidants are believed to protect the body against destructive effect of ROS. They act as scavengers helping to prevent cell and tissue damage as well as diseases (Reiter et al., 2004). The body produces several antioxidants which include SOD, CAT and GSH. SOD and CAT are enzymic antioxidants. SOD is a manganese containing enzyme that catalyzes superoxide radicals by accelerating the dismutation of superoxide to form hydrogen peroxide while the CAT, a peroxisomal heme protein, and catalyses the removal of the hydrogen peroxide formed into water (Nohl et al., 2003). GSH is a non enzymic antioxidant that exists in both reduced and oxidized states that neutralizes free radicals and aldehyde directly (Molavin et al., 2015). In the groups administered with $300 \mathrm{mg} / \mathrm{kg}$ body weight of the extracts, the increased levels of these enzymes may be an indication of the antioxidant potentials to counteract the oxidative effects and restore redox balances and important homeostasis (Akomolafe et al., 2015).

Further, results obtained from the standard drug treated group which was not administered with the combined ratio of the extracts show results that are comparable to control in all parameters investigated. This is an indication that the drug is a stronger anti-diabetic agent.

The biochemical results obtained from this study correlates with histopathological examinations of the pancreas and liver supporting claims made by earlier researchers (Peschke et al., 2005, Ankur and Shahjad, 2012., Dokubo et al., $2017 \mathrm{~b}$ ). Treatment with $300 \mathrm{mg} / \mathrm{kg}$ body weight of ethanol extracts of $P$. guineense and T. conophorum leaves showed good cellularity on the pancreas and liver ameliorating damages brought about by alloxan.

From the findings of this study, it can be concluded that $300 \mathrm{mg} / \mathrm{kg}$ body weight of $P$. guineenseand $T$. conophorum exhibited hypoglycemic and antioxidant potentials ameliorating damages brought about by alloxan. 


\section{References}

1. Akomolafe, S. F., Ganiyu, O., Afolabi, G.O., Akindahunsi, A. and Anthony, J. A. (2015). Antiperoxidative Activity of Tetracarpidium conophorum Leaf Extract in Reproductive Organs of Male Rats. Evidence-Based Complementary and Alternative Medicine.1: 8.

2. Amaeze, O. U., Ayoola, G. A., Sofidiya, M. O, Adepoju-Bello, A. A., Adegoke, A. O. and Coker, H. A. B. (2011). Evaluation of Antioxidant Activity of Tetracarpidium conophorum (Müll. Arg) Hutch \& Dalziel Leaves. Oxidative Medicine and Cellular Longevity. : 1- 7.

3. Ankur, R., and Shahjad, A. (2012). Alloxan Induced Diabetes: Mechanisms and Effects. International Journal of Research in Pharmaceutical and Biomedical Sciences. 3 (2): 819-823.

4. Baldi, A., Goyal S .(2011). Hypoglycemic Effect of Polyherbal Formulation in Alloxan Induced Diabetic Rats. Pharmacologyonline 3: 764-773.

5. Carvalho, M. G., DaCosta, P. M. ( 2009). Outros constituintes isolados de Licania arianeae (Chrysobalanaceae). Brazil Journal of Pharmacognsy. 19(1B):290-293.

6. Costa, V.and Moradas-Ferrerira, P. (2001). Oxidative stress and signal transduction in Saccharomyces cerevisiae: Insight into ageing, apoptosis and diseases. Molecular Aspects of Medicine. 22: 4-5.

7. Das, J., Vasan, V., Sil, P.C.(2012). Taurine exerts hypoglycemic effect in alloxan-induced diabetic rats, improves insulin-mediated glucose transport signaling pathway in heart and ameliorates cardiac oxidative stress and apoptosis. Toxicol Applied Pharmacology. 258:296-308.

8. Devasagayam, T. P. A., Bloor, K. K Ramasarma, T. (2003). Methods of Estimation of lipid peroxidation Analysis of merits \& demerits. Indian journal of Biochemistry and Biophysics. 40:300-308.

9. Dokubo A., Uwakwe, A.A. Amadi, B.A. (2017a). A Study on the Antioxidant and Anti inflammatory Effects of Aframomum Sceptrum and Parinari congensis Seed Extracts in Alloxan-Induced Diabetic Wistar Rats. EPRA International Journal of Research and Development. (2)7: 1-8.

10. Dokubo A., Uwakwe, A.A. Amadi, B.A. (2017b). Effects of Aframomum Sceptrum an Parinari congensis Seed Extracts in Alloxan Induced-Diabetic Wistar Rats. International Journal of Agriculture and Earth Science. (3 )5: 20-24.

11. Ellman, G.L (1959). Tissue sulphydryl groups. Archives of Biochemistry \& Biophysics. 82:70-77.

12. Erhirhie, E.O., Ekene, N.E. S.I., Ajaghaku, D.L (2014.) Guidelines on dosage calculation and stock solution preparation on experiential animals' studies. Journal of Natural Science Research. 2224-3186.

13. Ibrahim, M. A., Koorbanally, N. A., Kiplimo, J. J., Islam, M. S. (2012). Anti-oxidative activities of the various extracts of stem bark, root and leaves of Ziziphus mucronata(Rhamnaceae) in vitro. Journal of Medicinal and Plant Research. 6(25): 4176-4184.

14. Klein, J. A. and Ackerman, S.L. (2003). Oxidative stress, cell cycle and neurodegeneration. Journal of Clinical Investment. 111: 785-793.

15. Knip, M., (2011). Pathogenesis of type 1 diabetes: implications for incidence trends. Horm Research Paediatrics. 76(Suppl. 1): 57-64.

16. Li, Y., Zhang, T., Korkaya, H., Liu, S., Lee, H.F., Newman, B., Yu, Y., Clouthier, S. G.,Schwartz, S.J., Wicha, M. S., Sun, D (2010). Sulforaphane, a dietary component ofbroccoli/broccoli sprouts, inhibits breast cancer stem cells. Clinical CancerResearch.16(9):2580-2590.

17. Marklund, S.L. and Marklund, G. (1974). Involvement of superoxide anion radical in the auto- oxidation of pyrogallol and convenient assay for superoxide dismutase. EuropeanJournal of Biochemistry, 47: 469.

18. Molavian, H., Tonekaboni, A. M., Kohandel, M. \& Sivaloganathan, S. (2015). The Synergetic Coupling among the Cellular Antioxidants Glutathione Peroxidase/Peroxiredoxin and Other Antioxidants and its Effect on the Concentration of $\mathrm{H}_{2} \mathrm{O}_{2}$. Science Journal, 5: 1-8.

19. Nohl, H., Koziov, A.V, Gille, L. and Staniek, L. (2003). Cell respiration and formation of reactive oxygen species: facts and artfacts. Biochem Soc Trans. 31: 1308-1311.

20. Obomanu, F. G. Igwe, F.U. Olabiyi, O. C. (2017). Assessment of Synergistic HypoglycemicEffects ofTetracarpidium Conophorum andPiper Guineense In Alloxan- Induced Hyperglycemic Rats. EPRA International Journal of Research and Development. (2)8: 15-24.

21. Obomanu, F.G., Mba, M.A., Adiukwu, P.U. (1991).Nutritional Value and Mineral Contents of Ashantipepper(Piper guineense): Chemical, Phytochemical and NutritionalInvestigations of the Fruit(Berries). Journal of the Chemical Society of Nigeria. 16(9); 13.

22. Ojinaka, M.C., Odimegwu, E. N., Chidiebere, F.E. (2016).Comaparative Study of the Nutrient and Antinutrient Composition of the Seeds and Leaves of Uziza (Piper guineense). Journal of Environmental Science, Toxicology and Food Technology. 10(8) 42-48. 
23. Ozougwu, J.C., Obimba, K. C., Belonwu, C. D., and Unakalamba, C. B. (2013). The pathogenesis and pathophysiology of type 1 and type 2 diabetes mellitus. Journal of Physiology and Pathophysiology. 4:46-57.

24. Peschke, E., Ebelt, H., Bromme, H. J., Peschke, D. (2005). Classical and new diabetogencomparison of their effects on isolated rat pancreatic islets in vitro. Cell Molecular and Life Science. 57:158-164.

25. Petchi, R. R., Vijaya, C., \& Parasuraman, S. (2014).Antidiabetic Activity of Polyherbal ormulation in Streptozotocin - Nicotinamide Induced Diabetic Wistar Rats. Journal of Traditional and ComplementaryMedicine. 4(2), 108-117.

26. Reiter, R.I., Yan, D.X., Gitto, E., Sainz, R.M., Mayo, J.C, Lean, J., Manchester, L.C; Vijayalaxm, K.E \& Killic, U. (2004). Pharmacological utility of melatonin in reducing oxidative cellular and molecular damage. Pilard Journal of Pharmacology. 56(2): 159-170.

27. Schafer, F. and Buettner, G. (2001). Redox environment of the cells as viewed through the redox state of the glutathione disulfide/glutathione coupe. Free Radical Bio. Med. (30)11: 191-212.

28. Shina, A.K (1972). Colorimetic assay of Catalase. Analytical Biochemistry. 47: 389-394.

29. Stumvoll, M., Goldstein, B.J, van Haeften, T.W. (2005). Type 2 diabetes: principles of pathogenesis and therapy. Lancet. 365:1333-46.

30. Uddin, S.N., Akond, M.A., Mubassara, S., and Yesmin M. N .(2008). Antioxidant an Antibacterial activities of Tremacannabina. Middle-East Journal of Scientific Research. 3: 105-108. 